\title{
PENGARUH LIKUIDITAS, SOLVABILITAS DAN AKTIVITAS TERHADAP PROFITABILITAS PADA PERUSAHAAN MIRA-MAR BLOCK DILI TIMOR LESTE
}

\author{
Alexandre de Jesus lay ${ }^{1}$ \\ I.G.B. Wiksuana ${ }^{2}$ \\ ${ }^{1,2}$ Fakultas Ekonomi dan Bisnis Universitas Udayana (Unud), Bali, Indonesia \\ E-mail : alexandrelay123@gmail.com
}

\begin{abstract}
ABSTRAK
Tujuan dari penelitian ini adalah untuk mengetahui pengaruh Likuiditas, Solvabilitas, dan Aktivitas terhadap Profitabilitas pada Perusahaan Mira Mar-Block Dili Timor leste. Data yang digunakan bersuber dari laporan keuangan di perusahan Mira Mar Block Dili Timor Leste berupa Neraca dan Laporan Rugi Laba. setelah data dikumpulkan selanjutnya dianalisis dengan mengunakan model analisis regresi linear berganda. Model analisis ini digunakan uji normalitas, uji autokorelasi, ujimultikolinearitas, dan uji ketetapan model Regresi. Hasil analisis Regresi Linear Berganda menujukan bahwa Rasio Likuiditas (CR), Rasio Likuiditas berpengaruh signifikan terhadap Profitabilitas (ROE), sementara rasio Solvabilitas ( DER) dan rasio Aktivitas (TATO) berpengaruh tidak signifikan terhadap Profitabilitas ( ROE).
\end{abstract}

Kata Kunci : Pengaruh likuiditas, solvabilitas, dan aktivitas terhadap profitabilitas

\begin{abstract}
The aim of the study was to determine the effect of Liquidity, Solvency, and Activity on the profitability of the company of Mira Mar-Block Dili East Timor. The data used was obtained from the financial statements of the company of Mira-Mar Block, Dili, East Timor, in the form of Balance Sheet and Income Statement. After the data was collected then analyzed by using multiple linear regression analysis models. This analysis model used normality test, autocorrelation, multi co-linearity test, and permanent test of regression models. The Multiple Linear Regression analysis results showed that the Liquidity Ratio (CR) significantly effects on the Profitability (ROE), while the Solvency Ratio (DER) and the Ratio of Activity (TATO) do not significantly effect on the Profitability (ROE).
\end{abstract}

Keywords : Influence of liquidity, solvency, profitability and activity against 


\section{PENDAHULUAN}

\section{Latar Belakang}

Perkembangan ekonomi Timor leste yang semakin pesat, menyebabkan berkembangnya usaha pada perusahaan - perusahaan yang berorientasi profit baik itu perusahaan dagang, perusahaan jasa maupun perusahaan manufaktur dalam kegiatan usahanya semakin kompleks dan dinamis. Pencapaian perekonomian yang maju dalam suatu negara maka, selain dari sektor pemerintah, sektor swasta juga berperan penting dalam hal ini memberikan kontribusi bagi kemajuan ekonomi suatu negara.

Perusahaan diperlukan untuk perngembangan ekonomi suatau negara menurut Warsidi dan Bambang (2000:4) kinerja keuangan perusahaan yang sehat akan membantu meningkatkan taraf hidup perekonomian masyarakat pada suatu negara. Pencapaian kinerja keuangan yang sehat menuntut manajer perusahaan agar dapat mengevaluasi dengan menganalisis laporan keuangan pada setiap periode agar dapat diketahui apakah kinerja keuangan perusahaan tersebut dalam keadaan sehat atau sebaliknya. Perusahaan yang kinerja keuangannya sehat atau mengalami perkembangan adalah Perusahaan yang mampu mengelola tingkat Profitabilitas perusahaan dengan baik agar meningkat dari tahun ke tahun.

Perkembangan posisi keuangan mempunyai arti yang sangat penting bagi perusahaan untuk melihat sehat tidaknya suatu perusahaan tidak hanya dinilai dari keadaan fisiknya saja. Berdasarkan dari unsur tersebut, manajer dapat mengevaluasi apakah kebijakan yang ditempuh dalam perusahaan sudah tepat 
atau belum, mengingat sudah begitu kompleksnya permasalahan yang dapat menyebabkan kebangkrutan dikarenakan banyaknya perusahaan yang akhirnya gulung tikar karena faktor keuangan yang tidak sehat. Analisis keuangan pada dasarnya ingin melihat prospek dan risiko perusahaan. Prospek bisa dilihat dari tingkat keuntungan (profitabilitas) dan risiko bisa dilihat dari kemungkinan perusahaan mengalami kesulitan keuangan atau kebangkrutan. Untuk menghindari kebangkrutan tersebut maka seorang manajer perusahaan harus selalu berusaha agar perusahaannya dapat terus berjalan atau dengan kata lain manajer tersebut dapat menjaga kelangsungan hidup perusahaannya dari satu periode ke periode lainnya. Seorang manajer harus dapat mengetahui kondisi keuangan perusahaannya, karena pada dasarnya kondisi keuangan tersebut akan mempengaruhi kelangsungan hidup perusahaannya secara keseluruhan.

Menurut Kasmir (2012:310) mengatakan bahwa salah satu alat yang dipakai untuk mengetahui kondisi keuangan dalam hal ini tingkat profitabilitas suatu perusahaan adalah berwujud laporan keuangan ( financial report) yang disusun pada setiap akhir periode yang berisi pertanggung jawaban dalam bidang keuangan atas berjalannya suatu usaha. Laporan keuangan merupakan hasil dari proses akuntansi yang dapat digunakan sebagai alat komunikasi antara data financial atau aktivitas suatu perusahaan dengan pihak-pihak lain yang berkepentingan dengan data atau aktivitas tersebut. Data financial yang dimaksud adalah data yang tercermin dalam laporan keuangan, yang memberikan gambaran tentang keuangan suatu perusahaan, yang terdiri dari laporan Neraca, Laba-rugi serta laporan keuangan lainnya. Dengan mengadakan analisis terhadap pos-pos 
Alexandre de Jesus Lay, I.G.B. Wiksuana., Pengaruh Likuiditas, Solvabilitas, dan Aktivitas..

neraca akan dapat diperoleh gambaran tentang posisi keuangan perusahaan, sedangkan analisa terhadap laporan laba-rugi akan memberikan gambaran tentang hasil atau perkembangan usaha perusahaan yang bersangkutan. Untuk mengukur kinerja keuangan perusahaan dapat digunakan analisis rasio keuangan yang terdiri dari rasio Likuiditas, Solvabilitas dan Profitabilitas.

Menurut Riyanto (1995 : 25) mengatakan bahwa Pengelolaan dana pada perusahaan industri biasanya dihadapkan dengan masalah likuiditas. Likuiditas adalah menunjukkan kemampuan suatu perusahaan untuk memenuhi kewajiban keuangannya yang harus segera dipenuhi, atau kemampuan perusahaan untuk memenuhi kewajiban keuangan pada saat ditagih. Jadi perusahaan Mira-Mar Block dikatakan likuid apabila perusahaan tersebut mampu membayar semua hutang jangka pendek pada saat jatuh tempo. Selain itu Menurut Zaki Baridwan (2000:3) Tujuan utama perusahaan dalam kegiatan usahanya adalah menghasilkan laba. Laba adalah kenaikan modal (aktiva bersih) yang berasal dari transaksi sampingan atau transaksi yang jarang terjadi dari suatu badan usaha, dan dari semua transaksi atau kejadian lain yang mempengaruhi badan usaha selama suatu periode kecuali yang timbul dari pendapatan (revenue) atau investasi oleh pemilik. Dengan laba yang diperoleh, maka perusahaan Mira Mar Block Dili Timor Leste ini akan lebih mampu meningkatkan kegiatan operasionalnya terutama dapat meningkatkan volume penjualannya, sehingga tingkat Profitabilitas nya semakin meningkat. Jadi dengan meningkatnya Profitabilitas itu maka perusahaan akan lebih mampu membagikan dividen pada pemilik 
perusahaan (pemegang saham) yang telah menginvestasikan dananya pada perusahaan itu.

Berdasarkan konsep diatas, maka dalam penelitian ini variabel rasio Likuiditas, rasio Solvabilitas dan rasio Aktivitas akan dipergunakan sebagai variabel-variabel bebas yang berpengaruh terhadap profitabilitas, dimana profitabilitas diproyeksikan dengan return on assets (ROA).

Dalam kondisi perekonomian yang terus berkembang sektor perusahaan memiliki potensi dan peluang yang besar dalam peranannya sebagai sumber pembiayaan bagi masyarakat dan sektor usaha. Masyarakat dan sektor usaha sebagai pihak penguna jasa perusahaan yang paling berperan, pada umumnya selalu memiliki respon yang tanggap terhadap berbagai bentuk lainnya yang diberikan oleh masing-masing perusahaan untuk menarik atau simpati. Perusahaan atau lembaga yang sangat bergantun pada kepercayaan tentang menyempurnakan lainnya ditengah persaingan dengan banyaknya menyedia jasa keuangan lainnya.

Keuangan menunjukan kondisi keuangan dan hasil usaha, suatu usaha yang digunakan perusahaan dan juga digunakan oleh para pemakai sesuai dengan kepentingan masing-masing laporan keuangan, merupakan bagian dari proses pelaporan keungan (yang dapat disajikan dalam berbagai cara misalnya sebagai laporan arus dana) catatan dan laporan serta materi penjelasan merupakan bagian integral dalam laporan keuangan (Muhamad Yusup dan Soraya 2004:100).

Perkembangan di dunia perusahaan yang sangat pesat serta tingkat kompleksitas yang tinggi dapat perencanaan laba. Kompleksitas usaha yang tinggi 
Alexandre de Jesus Lay, I.G.B. Wiksuana., Pengaruh Likuiditas, Solvabilitas, dan Aktivitas..

dapat meningkatkan laporan keuangan yang dihadapi oleh perusahaan-perusahaan yang ada di Timor Leste. Permasalahan perusahaan di Timor Leste antara lain perusahaan yang bersaing dengan perusahaan yang lain untuk mendapat laba pada perusahaan, peningkatkan penghasilan setiap periode baru mendapatkan laba pada perusahaan Mira Mar Block

Ini berarti semakin efesien biaya yang dikeluarkan perusahaan untuk menunjukan kegiatan penjualan sehingga pendapatan yang diperoleh menjadi meningkat. Demikian perusahaan Timor-Leste sehingga menyebabkan meningkatnya laba. Lemahnya kondisi internal perusahaan seperti manajemen yang kurang memadai. Memberi informasi kepada kelompok atau usaha sendiri serta modal yang tidak dapat dalam laporan keuangan yang dihadapi oleh perusahaan Mira Mar Block tersebut menyebabkan laba perusahaan lebih menurun.

Penurunan pendapatan pada perusahaan Mira Mar Block dapat menurunkan pula kepercayaan masyarakat. Perencanaan laba bukan merupakan hal yang mudah, karena penerapannya harus didasarkan pada pertimbanganpertimbangan keadaan interen maupun eksteren perusahaan baik yang langsung maupun tidak langsung mempengaruhi penetapan laba itu sendiri. Faktor eksteren yang perlu dipertimbangkan manajemen dalam perencanaan laba ini adalah kondisi perekonomian pada umumnya, tingkat populasi penduduk, pendapatan dan daya beli masyarakat, kemajuan teknologi, kebijaksanaan pemerintah dan lain-lain, yang kesemuanya ini sulit diramalkan secara baik. Sedangkan faktor interen yang perlu dipertimbangkan yaitu keadaan perusahaan itu sendiri berupa 
besarnya volume penjualan yang diinginkan untuk mencapai laba tertentu, bagaimana kemampuan kapasitas yang ada baik peralatan maupun personil yang ada, kemampuan keuangan dan sebagainya. Perencanaan merupakan serangkaian tindakan untuk mencapai suatu hasil yang diinginkan. Pada dasarnya perencanaan itu merupakan fungsi manajemen yang berhubungan dengan pemilihan berbagai alternatif tindakan dan perumusan kebijakan. Suatu perencanaan bisa terealisir apabila manajemen berhasil dalam menjalankan perusahaan yang diukur dengan besarnya laba (profitability).

Inti dari pada laporan keuangan adalah keadaan keuangan perusahaan pada tanggal (untuk neraca) dan periode tertentu (untuk laporan laba rugi). Biasanya laporan keuangan dibuat per periode, misalnya tiga bulan, atau enam bulan untuk kepentingan perusahaan.

Jadi, dengan memperoleh laporan keuangan suatu perusahaan, maka akan dapat diketahui kondisi keuangan perusahaan secara menyeluruh. Kemudian laporan keuangan tidak hanya sekadar cukup dibaca saja, akan tetapi juga harus dimengerti dan dipahami tentang posisi keuangan perusahaan saat ini. Caranya dengan melakukan analisis keuangan melalui berbagai rasio keuangan yang lazim dilakukan. Disamping memiliki tujuan seperti yang telah dikemukakan di atas, laporan keuangan juga memiliki sifat tertentu. Demikian pula dengan pencatatan yang dilakukan dalam penyusunan laporan keuangan harus dilakukan dengan kaidah -kaidah yang berlaku.

Adapun untuk laporan lebih luas dilakukan 1 tahun sekali. Laporan keuangan merupakan alat yang sangat penting untuk memperoleh informasi 
Alexandre de Jesus Lay, I.G.B. Wiksuana., Pengaruh Likuiditas, Solvabilitas, dan Aktivitas..

sehubungan dengan posisi keuangan dan hasil-hasil yang telah dicapai oleh perusahaan yang bersaing.

Setiap perusahaan yang didirikan baik perusahaan dagang, perusahaan industri maupun perusahaan jasa memiliki satu tujuan utama yaitu mencapai laba maksimal. Setiap perusahaan berusaha untuk menerapkan strategi yang tepat sehingga dapat secara cepat merespons perkembangan pasar untuk dapat mempertahankan dan sekaligus merebut pasar dan peluang yang ada dimana terdapat para pesaing dari bidang usaha sejenis yang ketat berkompetisi. Informasi-informasi bisnis harus secara cepat dapat diperoleh sehingga pihak perusahaan dapat segera mengambil kebijakan yang diperlukan. Di samping kecepatan, keakuratan dari informasi yang diperoleh juga merupakan hal yang tidak kalah pentingnya dan menjadi aset yang sangat berharga bagi perusahaan dalam menerapkan kebijakan dan strategi-strateginya.

kecapaian kecepatan dan keakuratan informasi tidak akan berharga jika tidak dapat dianalisis dan di interpretasikan dengan baik dan tepat dalam kebijakan dan strategi yang dibuat oleh perusahaan. Hal ini menuntut kemampuan dan kejelian pihak manajemen perusahaan dalam menganalisis dan menginterpretasikan informasi tersebut khususnya informasi keuangan yang terdapat dalam laporan keuangan perusahaan.

Informasi mengenai kegiatan dimasa yang lalu dianalisa dan disesuaikan dengan keadaan dimasa sekarang untuk dijadikan dasar kebijaksanaan yang berguna sebagai dasar pengambilan keputusan. Dengan demikian, suatu 
keputusan tersebut tidak hanya didasarkan pada institisi manajer, melainkan suatu keputusan yang tepat dan lebih rasional.

Laporan keuangan adalah salah satu sumber informasi yang penting dalam hal pengambilan keputusan oleh pihak manajemen perusahaan karena menyangkut tentang posisi keuangan perusahaan baik dari segi Likuiditas, Solvabilitas, Rentabilitas, Aktivitas hasil-hasil atau kerugian yang dialami oleh perusahaan dalam suatu periode tertentu.

Dengan informasi dari laporan keuangan periode yang lalu, manajemen perusahaan dapat mengambil keputusan untuk kebijakan-kebijakan yang lebih tepat, membuat perencanaan yang lebih baik untuk periode yang akan datang serta memperbaiki sistem pengawasannya.

Salah satunya adalah untuk membuat perencanaan laba pada periode yang akan datang serta bagaimana cara untuk mencapai target laba yang sudah ditetapkan oleh perusahaan karena tingkat laba perusahaan memberikan kontribusi yang sangat besar bagi perkembangan dan kemajuan perusahaan.

Pada dasarnya untuk mengentahui kondisi keuangan perusahaan untuk mencapai tujuan perusahaan pada periode yang akan datang.

Hal inilah yang menarik, menjadi salah satu alasan untuk memilih judul Pengaruh Likuiditas, Solvabilitas dan Aktivitas terhadap Profitabilitas Pada Perusahaan Mira Mar Block Di Dili Timor-Leste.

\section{Tujuan Penelitian}

Berdasarkan rumusan masalah, maka metode penelitian ini adalah sebagai berikut: 
Alexandre de Jesus Lay, I.G.B. Wiksuana., Pengaruh Likuiditas, Solvabilitas, dan Aktivitas..

1) Untuk mengetahui signifikansi pengaruh rasio Likuiditas terhadap Profitabilitas pada Perusahaan Mira Mar Block di Dili Timor-Leste.

2) Untuk mengetahui signifikansi pengaruh rasio Solvabilitas terhadap Profitabilitas pada Mira Mar Block di Dili Timor-Leste.

3) Untuk mengetahui signifikansi pengaruh Aktivitas terhadap Profitabilitas pada Mira Mar Block di Dili Timor-Leste.

4) Untuk mengetahui signifikansi pengaruh Likuiditas, Solvabilitas dan Aktivitas secara simultan terhadap Profitabilitas pada Mira Mar Block di Dili Timor-Leste.

\section{Manfaat Hasil Penelitian}

\section{Manfaat Praktis}

Penelitian ini harapkan dapat memberikan informasi kepada manajemen Mira Mar Block sebagai dasar pengambilan keputusan dalam mengelola modal kerja dalam kaitannya dengan Profitabilitas.

\section{KAJIAN PUSTAKA}

\section{Profitabilitas}

Profitabilitas menurut Wiagustini (2010) adalah kemampuan perusahaan untuk menghasilkan laba selama periode tertentu Brigham and Dave (2010) mengemukakan bahwa profitabilitas adalah hasil bersih dari serangkaian kebijakan dan keputusan.

Profitabilitas adalah kemampuan perusahaan memperoleh laba dalam hubungannya dengan penjualan, total aktiva maupun modal sendiri (Sartono 
2010:122). Bagi perusahaan masalah Profitabilitas sangat penting. Bagi pimpinan perusahaan, Profitabilitas digunakan sebagai tolak ukur berhasil atau tidaknya perusahaan yang dipimpinnya. Sedangkan bagi karyawan perusahaan semakin tinggi Profitabilitas yang diperoleh oleh perusahaan, maka ada peluang untuk meningkatkan gaji karyawan.

Profitabilitas yang tinggi akan dapat mendukung kegiatan operasional secara maksimal. Tinggi rendahnya Profitabilitas dipengaruhi banyak faktor seperti modal kerja. Aktivitas operasional setiap perusahaan akan membutuhkan potensi sumberdaya, salah satunya adalah modal. Modal merupakan masalah utama yang akan menunjang kegiatan operasional perusahaan dalam rangka mencapai tujuannya (Bramasto,2008).

Setiap perusahaan selalu berusaha untuk meningkatkan profitabilitasnya. Jika perusahaan berhasil meningkatkan Profitabilitasnya, dapat dikatakan bahwa perusahaan tersebut mampu mengelola sumberdaya yang dimilikinya secara efektif dan efisien sehingga mampu menghasilkan laba yang tinggi, sebaliknya, sebuah perusahaan memiliki Profitabilitas yang rendah menunjukkan bahwa perusahaan tersebut tidak mampu mengelola sumber daya yang dimilikinya dengan baik, sehingga tidak mampu menghasilkan laba tinggi. rasio Profitabilitas adalah rasio yang bertujuan untuk mengukur efektifitas manajemen yang tercermin pada imbalan hasil dari investasi melalui kegiatan penjualan ( Djarwanto, 2001). Sedangkan menurut Brigham dan Dave (2010), rasio Profitabilitas adalah rasio yang menunjukkan pengaruh gabungan dari Likuiditas, 
Alexandre de Jesus Lay, I.G.B. Wiksuana., Pengaruh Likuiditas, Solvabilitas, dan Aktivitas..

pengelolahan aktiva dan pengelola hutang terhadap hasil-hasil operasional perusahaan.

Menurut Kasmir (196) Pergertian Profitabilitas adalah tujuan akhir yang ingin dicapai suatu perusahan yang terpentig adalah memperoleh laba atau keuntungan yang maksimal disamping hal-hal laing. Dengan memperoleh laba yang maksimal yang maksimal seperti yang telah ditargetkan, perusahan dapat membuat banyak lagi

Adapun jenis-jenis rasio keuangan yang sering digunakan yaitu:

1. Rasio Likuiditas

2. Rasio Solvabilitas

3. Rasio Aktivitas.

4. Rasio Rentabilitas (Profitabilitas)

\section{Pengertian Likuiditas (Current Ratio)}

Menurut Irham Fahmi, (2012:121) menyebutkan bahwa rasio Likuiditas (likuidity ratio) merupakan rasio yang memggambarkan kemampuan perusahaan memenuhi kewajiban (utang) jangka pendek. Artinya apabila perusahaan ditagih, maka akan mampu untuk memenuhi utang (membayar) tersebut terutama utang yang sudah jatuh tempo. Jenis-jenis rasio likuiditas yang dapat digunakan terdiri dari :

a. Rasio Lancar (Current Ratio atau Rasio lancar), merupakan rasio untuk mengukur kemampuan perusahaan membayar kewajiban jangka pendek atau utang yang segera jatuh tempo pada saat ditagih secara keseluruhan. Dengan kata 
lain, seberapa banyak aktiva lancar yang tersedia untuk menutupi kewajiban jangka pendek yang segerah jatuh tempo. Rasio lancar dapat pula dikatakan sebagai bentuk untuk mengukur tingkat keamanan (margin of safety) suatu perusahaan. Rasio ini mengunakan rumus sebagai berikut:

Rasio Lancar $=\frac{\text { Aktiva Lancar }}{\text { Hutan Lancar }} \times 100 \%$

b. Rasio Cepat (Quick Ratio)

Rasio cepat (quick ratio) atau rasio sangat lancar atau acid test ratio merupakan rasio yang menunjukan kemampuan perusahaan memenuhi atau membayar kewajiban atau utang lancer(utang jangka pendek) dengan aktiva lancar tanpa memperhitungkan nilai sediaan (inventory). Artinya, nilai sediaan kita abaikan, dengan cara dikurangi dari nilai total aktiva lancar.

Hal ini dilakukan karena sediaan dianggap memerlukan waktu relatif lebih lama untuk diuangkan, apabila perusahaan membutuhkan dana cepat untuk membayar kewajiban dibandingkan dengan aktiva lancar lainnya.

Rasio ini mengunakan rumus sebagai berikut:

$$
\text { Rasio cepat }=\frac{\text { Aktiva Lancar }- \text { persediaan }}{\text { Hutan Lancar }} \times 100 \%
$$

c. Rasio Kas atas Aktiva Lancar

Rasio ini menunjukan porsi jumlah kas dibandingkan dengan total aktiva lancar.

Rasio ini dapat dihitung denan rumus sebagai berikut:

RasioKasatasAktivaLancar $=\frac{\text { Kas }}{\text { Aktiva Lancar }} \times 100 \%$

d. Rasio Kas atas Hutang Lancar 
Alexandre de Jesus Lay, I.G.B. Wiksuana., Pengaruh Likuiditas, Solvabilitas, dan Aktivitas..

Rasio ini menunjukan porsi kas yang dapat menutupi hutang lancar. Rasio ini dapat dihitung dengan rumus sebagai berikut:

Rasio Kas atas Hutang Lancar $=\frac{\text { Kas }}{\text { Hutang Lancar }} \times 100 \%$

Likuiditas perusahaan merupakan kemanpuan perusahaan untuk menyelesaikan kawajiban-kewajiban jangka pendeknya atau menagalisis dan menginterprestasikan posisi keuangan jangka pendeknya perusahaan ( Munawir,2002 ).Tingkat Likuiditas perusahaan dapat diukur melalui current ratio. Current ratio dihitung dengan cara aktiva lancar dibagi hutang lancar. Rasio ini menunjukkan sejauhmana aktiva lancar dengan hutang lancar menutupi kewajiban-kewajiban lancar. Rasio ini menggunakan rumus sebagai berikut:

Rasio Lancar $=\frac{\text { Aktiva Lancar }}{\text { Hutan Lancar }} \times 100 \%$

\section{Pengertian Solvabilitas (Debt to Equity Ratio)}

Menurut Irham Fahmi, (202:12) menyatakan bahwa Rasio Solvabilitas merupakan rasio yang menunjukkan bagaimana perusahaan mampu untuk mengelola hutangnya dalam rangka memperoleh keuntungan dan juga mampu untuk melunasi kembali hutangnya.

Ada beberapa rasio Solvabilitas yaitu:

a. Rasio Hutang atas Modal

Rasio ini menggambarkan sejauhmana modal pemilik dapat menutupi hutang kepada pihak luar. Rasio ini disebut juga rasio leverage.

Rasio ini dapat dihitung dengan rumus sebagai berikut: 
Rasio Hutang atas modal $=\frac{\text { Total Hutang }}{\text { Modal (equity) }} \times 100 \%$

b. Rasio Hutang atas Aktiva

Rasio ini menggambarkan sejauh mana aktiva pemilik dapat menutupi hutang kepada pihak luar.

Rasio ini dapat dihitung dengan rumus sebagai berikut:

$$
\text { Rasio hutang atas aktiva }=\frac{\text { Total Hutang }}{\text { Total Aktiva }} \times 100 \%
$$

Solvabilitas merupakan rasio yang menunjukan bagaimana perusahaan mampu untuk mengelola hutangnya dalam rangka memperoleh keuntungan dan juga mampu untuk melunasi kembali hutangnya.

\section{Pengertian Rasio Aktivitas}

Menurut Irham Fahmi,(2012:132) Menyatakan bahwa rasio Aktivitas yang menggambarkan sejauhmana suatu perusahaan mempergunakan sumber daya yang dimilikinya guna menunjang aktivitas perusahaan, dimana penggunaan aktivitas ini dilakukan secara sangat maksimal dengan maksud memperoleh hasil yang maksimal. Rasio ini menunjukan beberapa kali nilai aktiva berputar bila diukur dari volume penjualan.

Rasio ini dapat dihitung dengan rumus:

$$
\text { Fixed Asset Turnover }=\frac{\text { penjualan }}{\text { aktiva tetap }} \times 100 \%
$$

Rasio ini menunjukan perputar total aktiva diukur dari volume penjualan dengan kata lain seberapa jauh kemampuan semua aktiva menciptakan penjualan. 
Alexandre de Jesus Lay, I.G.B. Wiksuana., Pengaruh Likuiditas, Solvabilitas, dan Aktivitas..

Rasio ini dapat dihitung dengan rumus:

Rasio Aktivitas yang mengambarkan sejauh mana suatu perusahaan mempergunakan sumber daya yang dimilikinya guna menunjang aktivitas perusahaan, dimana penggunaan aktivitas ini dilakukan secara sangat maksimal dengan maksud memperoleh hasil yang maksimal.

Rasio ini dapat dihitung dengan rumus:

Fixed Asset Turnover $=\frac{\text { penjualan }}{\text { aktiva tetap }} \times 100 \%$

\section{Hubungan Rasio Likuiditas dengan Profitabilitas}

Likuiditas merupakann kemampuan perusahaan dalam membayar kewajibankewajiban jangka pendeknya dengan menggunakan aktiva lancar yang dimiliki. Dalam hubungannya dengan Likuiditas makin kecil Likuiditas, perusahaan kurang likuid sehingga tidak dapat membayar para krediturnya. Semakin besar Likuiditas perusahaan maka semakin mampu pula perusahaan dalam membayar kewajiban-kewajiban jangka pendeknya dengan tepat waktu. Maka rendah nilai current ratio menunjukkan semakin rendah kemampuan perusahaan dalam menutupi kewajiban jangka pendeknya.

\section{Hubungan Rasio Solvabilitas dengan Profitabilitas}

Solvabilitas merupakan rasio yang menunjukan bagaimana perusahaan mampu untuk mengelola hutangnya dalam rangka memperoleh keuntungan dan juga mampu untuk melunasi kembali hutangnya.

\section{Hubungan Rasio Aktivitas dengan Profitabilittas}


Rasio Aktivitas yang menggambarkan sejauh mana suatu perusahaan memperguan sumber daya yang dimilikinya guna menunjang aktivitas perusahaan, dimana penggunaan Aktivitas ini dilakukan secara sangat maksimal dengan maksud memperoleh hasil yang maksimal. Rasio ini menunjukan beberapa kali nilai aktiva berputar bila diukur dari volume penjualan.

\section{Laporan Keuangan}

\section{Pengertian laporan keuangan}

Analisis laporan keuangan terdiri dari dua kata yaitu analisa dan laporan keuangan untuk menjelaskan analisa adalah memecahkan atau mengguraikan sesuatu unit menjadi berbagai unit terkecil. Sedangkan laporan keuangan adalah neraca, laba atau rugi, dan arus kas (Dana). kalau dua pengertian ini di gabungkan maka analisa laporan berarti, untuk mengguraikan pos-pos laporan keuangan menjadi unit informasi yang lebih kecil dan melihat hubungan yang bersifat signifikan atau yang mempunyai makna antara satu dengan yang lain baik antara kuantitatif maupun non kuantitatif dengan tujuan untuk mengetahui kondisi keuangan lebih dalam yang sangat penting dalam proses menghasilkan keputusan yang tepat (Sofian Syarrifi Hararap, 2001:192).

Laporan keuangan merupakan suatu informasi yang mengambarkan kondisi keuangan suatu perusahaan, dan lebih jauh informasi tersebut dapat dijadikan sebagai gambaran kinerja keuangan perusahaan tersebut, (Irham Fahmi, 2012:2).

Disisi lain Farid Harianto dan Siswanto Sudomo (1998:179) mengatakan laporan keuangan merupakan informasi yang diharapkan mampu memberikan 
Alexandre de Jesus Lay, I.G.B. Wiksuana., Pengaruh Likuiditas, Solvabilitas, dan Aktivitas..

bantuan kepada pengguna untuk membuat keputusan ekonomi yang bersifat finansial.

Lebih lanjut Munawir, (2002:56) mengatakan bahwa, laporan keuangan alat yang sangat penting untuk memperoleh informasi sehubungan dengan posisi keuangan dan hasil-hasil yang telah dicapai oleh perusahaan yang bersangkutan.

Secara lebih tegas Sofyan Assauri (2000:29) mengatakan bahwa laporan keuangan merupakan pertanggung jawaban manajemen sumber daya yang dipercayakan kepadanya.

Menurut Standar Akuntansi Keuangan (Ikatan Akuntansi Indonesia, 1994) bahwa tujuan laporan keuangan adalah menyediakan infomasi yang menyangkut posisi kauangan, kinerja serta peruabahan posisis keuangan suatu perusahaan yang bermanfaat bagi sejumlah besar pemakai dalam pengambilan keputusan ekonomi.

Adapun tujuan laporan keuangan menurut PAPI (Pedoman Akuntansi Perbankan Indonesia) bahwa tujuan laporan keuangan adalah untuk memberikan informasi tentang posisi keuangan, kinerja perubahan ekuitas, arus kas dan informasi lainnya yang bermanfaat bagi pengunaan laporan dalam rangka membuat keputusan ekonomi serta menunjukan pertanggung jawaban manajemen atas pengunaan sumber daya yang dipercayakan kepada mereka.

Analisis laporan keuangan berarti melakukan suatu proses untuk membeda laporan keuangan dalam unsur- unsurnya. Menelah hubungan antara unsur-unsur tersebut dengan tujuan untuk memperoleh pengertian dan pemahaman yang baik dan tepat atas laporan keuangan tersebut ( Dwi Prastowo 2002 : 52 ). 
Analisis laporan keuangan untuk menunjukkan laporan keuangan dan usaha suatu perusahaan yang digunakan oleh para pemakai sesuai dengan kepentingan masing-masing analisa laporan keuangan merupakan bagian dari proses laporan keuangan yang di lengkapi laporan laba rugi neraca laporan arus kas laporan perubahan posisi keuangan (yang dapat disajikan dalam berbagai cara misalnya laporan arus kas atau laporan arus dana) catatan dan laporan keuangan (Muhamad Yusuf dan Soraya (2004: 100).

Analisis laporan keuangan suatu perusahaan pada dasarnya karena ingin mengetahui tingkat profitabilitas (keuntungan) dan tingkat risiko atau tingkat kesehatan suatu perusahaan.

Menurut Chen dan Shimerda, dalam Meythi (2007: 51) Analisis laporan keuangan adalah rasio keuangan yang dapat dihitung dari laporan keuagan. Rasio keuangan berhubungan dengan kinerja perusahaan dan membantu pemakai dalam memgambil keputusan keuangan.

Analisis laporan keuangan merupakan salah satu cara untuk mengetahui kinerja perusahaan dalam suatu periode. Seperti diketahui bahwa laporan keuangan, merupakan kewajiban merupakan kewajiban setiap perusahaan untuk menbuat dan melaporkannya pada suatu periode tertentu.

Secara umum dikatakan bahwa laporan keuangan adalah laporan yang menunjukan kondisi keuangan perusahaan pada saat ini atau suatu periode tertentu, Kasmir,(2009:66).

\section{Unsur-Unsur Laporan Keuangan}


Alexandre de Jesus Lay, I.G.B. Wiksuana., Pengaruh Likuiditas, Solvabilitas, dan Aktivitas..

Menurut Lyn M. Fraser dan Aileen Ormiston (2008:8-10) Menyatakan bahwa unsur-unsur laporan keuangan seperti berikut:

1) Neraca

2) Laporan laba rugi

3) Laporan perubahan modal

4) Laporan catatan atas laporan keuangan

5) Laporan arus kas.

Neraca merupakan laporan yang menunjukkan jumlah aktiva (harta), kewajiban (utang), dan modal perusahaan (ekuitas) perusahaan pada saat tertentu. Artinya dari suatu neraca akan tergambar berapa jumlah harta, kewajiban, dan modal suatu perusahaan.

Laporan laba rugi, menunjukkan kondisi usaha suatu perusahaan dalam suatu periode tertenu. Artinya, laporan laba rugi harus dibuat dalam suatu siklus operasi atau periode tertentu guna mengetahui jumlah perolehan pendapatan penjualan dan biaya yang telah dikeluarkan, sehingga dapat diketahui, perusahaan dalam keadaan laba atau rugi.

Laporan perubahan modal, merupakan laporan yang mengambarkan jumlah modal yang dimiliki perusahaan saat ini. Kemudian laporan ini juga menunjukan perubahan modal.

Laporan catatan atas laporan keuangan merupakan laporan yang di buat berkaitan dengan laporan keuangan yang disajikan. Laporan ini memberikan informasi tentang penjelasan yang diangap perlu atas laporan keuangan yang ada sehinga memjadi jelas sebab penyebabnya. 
Laporan arus kas, merupakan laporan yang menunjukkan arus kas masuk dan arus kas keluar di perusahaan. Arus kas masuk berupa pendapatan atau pinjaman dari pihak lain. Adapun arus kas keluar merupakan biaya-biaya telah di keluarkan perusahaan. Baik arus kas masuk maupun arus kas keluar di buat periode tertentu. Pengertian neraca menurut James C.Van Horne (2012:3) adalah ringkasan posisi keuanga. Perusahaan pada tanggal tertentu yang menunjukkan total aktiva dengan total kewajiban ditambah total ekuitas pemilik.

Berdasarkan pengertian diatas dapat dijelaskan bahwa neraca merupakan ringkasan laporan keuangan, artinya laporan keuangan disusun secara garis besarnya dan tidak mendetail.

Penyusunan neraca di mulai dari yang paling likuid (lancar), yaitu mulai dari aktiva lancar, aktiva tetap dan aktiva lainnya. Komponen yang terkandung dalam aktiva lancar adalah kas, bank, surat-surat berharga, piutang, persediaan, dan lainnya.

Kemudian aktiva tetap dibagi dua, yaitu aktiva tetap berwujud dan tidak berwujud. Komponen dalam aktiva tetap berwujud seperti tanah, bangunan, mesin, kendaraan, peralatan dan lainnya. Sedangkan aktiva tidak berwujud seperti paten, goodwiil, opsi dan lainnya.

Jenis laporan keuangan lainnya selain neraca adalah laporan laba rugi. Berbeda dengan neraca yang melaporkan informasi tentang kekayaan, utang dan modal, maka laporan laba rugi memberikan informasi tentang hasil-hasil usaha yang diperoleh perusahaan. Laporan laba rugi juga berisis jumlah pendapatan yang diperoleh dan jumlah biaya yang dikeluarkan. 
Alexandre de Jesus Lay, I.G.B. Wiksuana., Pengaruh Likuiditas, Solvabilitas, dan Aktivitas..

Laporan laba rugi memuat jenis-jenis pendapatan yang diperoleh perusahaan yang disamping jumlahnya (nilai uangnya) dalam satu periode kemudian melaporkan jenis-jenis biaya yang dikeluarkan berikut jumlahnya (nilai uangnya) dalam periode yang sama.

\section{Tujuan dan Sifat Laporan Keuangan.}

Secara umum laporan keuangan bertujuan untuk memberikan informasi keuangan suatu perusahaan, baik pada saat tertentu maupun pada periode tertentu. Laporan keuangan mampu memberi imformasi keuangan kepada pihak dalam dan luar perusahaan yang memiliki kepentingan terhadap perusahaan (Kasmir,(2010:68).

Berikut ini beberapa tujuan pembuatan atau penyusunan laporan keuangan yaitu:

a. Memberi imformasi tentang jenis dan jumlah aktiva (harta) yang dimiliki perusahaan pada saat ini.

b. Memberi imformasi tentang jenis dan jumlah kewajiban dan modal yang dimilki perusahaan pada saat ini.

c. Memberi imformasi tentang jenis dan jumlah pendapatan yang diperoleh pada suatu periode tertentu.

d. Memberi imformasi tentang jumlah biaya dan jenis biaya yang dikeluarkan perusahaan dalam suatu periode tertentu.

e. Memberi imformasi tentang perubahan yang terrjadi terhadap aktiva, pasiva, dan modal perusahaan. 
f. Memberikan imformasi tentang kinerja manajemen perusahaan dalam suatu periode.

g. Memberi imformasi tentang catatan atas laporan keuangan.

h. Imformasi keuangan lainnya.

Secara umum dikatakan bahwa tujuan dan manfaat dari analisis laporan keuangan adalah:

a. Untuk mengetahui posisi keuangan perusahaan dalam satu periode tertentu, baik harta, kewajiban, modal, maupun hasil usaha yang telah dicapai untuk beberapa periode.

b. Untuk mengetahui kelemahan apa saja yang menjadi kekurangan perusahaan.

c. Untuk mengetahui kekuatan yang dimiliki.

d. Untuk mengetahui langkah-langkah perbaikan apa saja yang perlu dilakukan ke depan yang berkaitan dengan posisi keuangan perusahaan saat ini.

e. Untuk melakukan penilaian kinerja manajemen ke depan apakah perlu penyegaran atau tidak karena sudah diangap berhasil atau gagal.

f. Dapat juga digunakan sebagai pembanding dengan perusahaan sejenis tentang hasil yang mereka capai.

\section{Teknik Analisis Laporan Keuangan}

Perbandingan adalah teknik analisis laporan keuangan yang dilakukan dengan Cara menyajikan laporan keuangan secara horizontal dan membandinkan antara satu dengan yang lain dengan menunjukan informasi keuangan atau data lainnya dalam nilai mata uang dalam unit, dapat juga dalam persentasi atau perbandigan (Kasmir, (2010:70). 
Alexandre de Jesus Lay, I.G.B. Wiksuana., Pengaruh Likuiditas, Solvabilitas, dan Aktivitas..

Hal yang perlu dipertimbangkan dalam melakukan analisis perbandingan Yaitu:

a. Standar penyusunan laporan keuangan harus sama.

b. Ukuran perusahaan yang akan dibandingkan harus diperhatikan jenis dan bentuknya.

c. Laporan keuangan yang dibandingkan harus sama khususnya untuk laporan laba rugi.

\section{KERANGKA BERPIKIR, KONSEPTUAL DAN HIPOTESIS PENELITIAN}

\section{Kerangka Berpikir Konseptual}

Profitabilitas menurut Van Horne (2005:222) adalah rasio yang menghubungkan laba dari penjualan dan rasio investasi. Dari rasio Profitabilitas dapat diketahui bagaimana tingkat Profitabilitas perusahaan. Setiap perusahaan menginginkan tingkat profitabilitas tinggi. Untuk dapat melangsungkan hidupnya, perusahaan harus berada dalam keadaan yang menguntungkan (profitabile). Apabila perusahaan berada dalam kondisi yang tidak menguntungkan, maka akan sulit bagi perusahaan untuk mempe roleh pinjaman dari kreditur maupun investasi dari pihak luar.

Profitabilitas perusahaan dipengaruhi oleh banyak faktor, modal kerja merupanak sala satu faktor yang mempengaruhi prifitabilitas perusahan.manajemen modal kerja yang baik ditunjukan oleh pengaruh posetif dari kebijakan-kebijakan modal terhadap profitabilitas perusahan. Berdasarkan kajian teori konsep tentang profitabilitas dan kebijaksanaan modal kerja yang berpengaruh terhadap profitabilitas. Manajemen modal kerja yang baik ditunjukan 
adanya kontribusi yang seimbang dari kebijakan-kebijakan modal kerja terhadap profitabilitas sehinga memaksimalkan profitabilitas perusahaan.

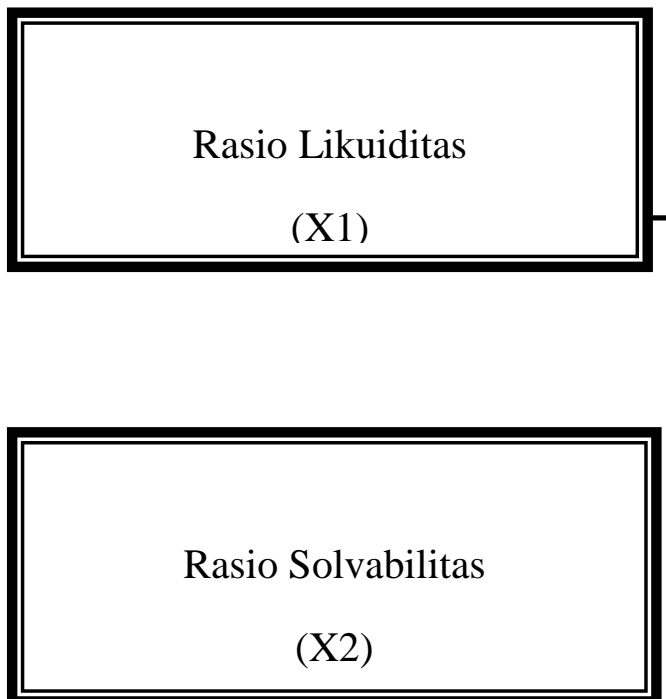

H1
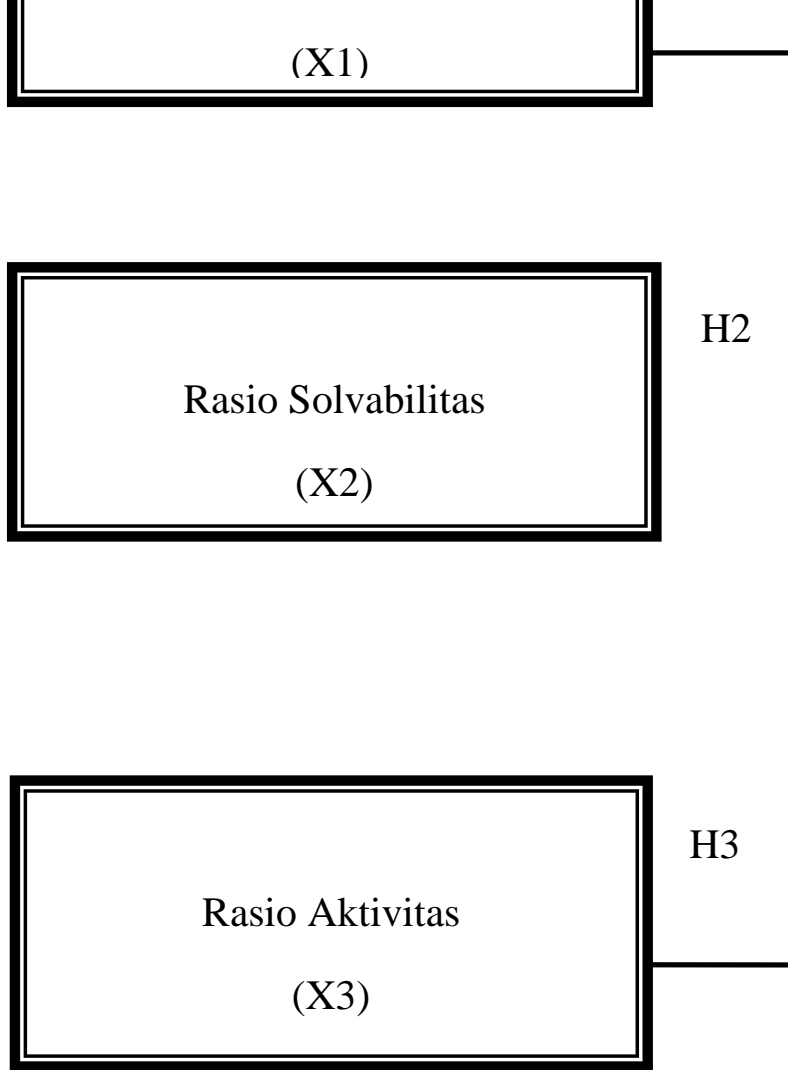

$\mathrm{H} 3$

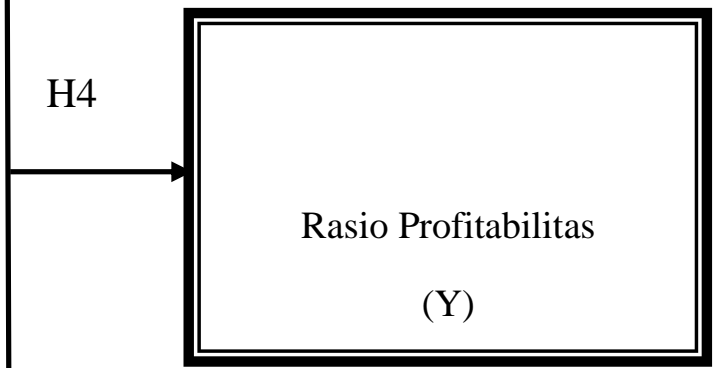

\section{Gambar 1}

Kerangka konsep pengaruh Likuiditas, Solvabilitas dan Aktivitas terhadap profitabilitas 
Alexandre de Jesus Lay, I.G.B. Wiksuana., Pengaruh Likuiditas, Solvabilitas, dan Aktivitas..

\section{METODE PENELITIAN}

Penelitian ini merupakan penelitian kausalitas, yaitu hubungann sebab akibat yang mengkaji tentang pengaruh efektivitas rasio Likuiditas, rasio Solvabilitas, Rasio Aktivitas terhadap Profitabilitas pada Mira Mar Block. Tujuan penelitian ini adalah untuk mengetahui hubungan antara dua variabel atau lebih (Sugiyono,2006). Hubungan antara variabel dalam penelitian ini adalah hubungan kausal.

Penelitian ini dilakukan pada periode tahun 2009 Sampai dengan 2014.

Penelitian ini ingin mengetahui tentang pengaruh variabel pengunaan Likuiditas, Solvabilitas, Aktivitas terhadap Profitabilitas perusahaan.

\section{Variabel Penelitian}

\section{Indentifikasi Variabel}

Variabel penelitian ini meliputi variabel Indepeden dan variabel Depeden. Variabel Indepeden adalah Variabel yang tidak dipengaruhi oleh variabel lainnya yaitu Likuiditas (X1), Solvabilitas (X2), Aktivitas (X3) sedangkan variabel Depeden adalah variabel yang dipengaruhi oleh variabel lainnya yaitu Profitabilitas (Y).

\section{Definisi Operasional Variabel}

Definisi operasional adalah suatu definisi yang diberikan kepada suatu variabel dengan cara memberikan arti, menspesifikasi kegiatan ataupun memberikan suatu operasional yang diperlukan, dalam penelitian ini untuk mempermudah dalam menyelesaikan permasalahan, maka perlu mengukur 
variabel-variabel yang digunakan, dimana variabel dependen (Y) yaitu Profitabilitas perusahaan dan variabel indepeden $(\mathrm{X})$ yaitu rasio Likuiditas (X1), rasio Solvabilitas (X2) rasio Aktivitas (X3), sebagai definisi operasional variablevariabel tersebut adalah:

1) Rasio Likuiditas (X1) merupakan rasio yang memggambarkan kemampuan perusahaan memenuhi kewajiban (utang) Jangka pendek. Artinya apabila perusahaan ditagih, maka akan mampu untuk memenuhi utang (membayar) tersebut terutama utang yang sudah jatuh tempo, pada perusahaan Mira Mar di Dili Timor-Leste dari tahun 2009 - 2014.

$$
\text { Rasio Lancar }=\frac{\text { Aktiva Lancar }}{\text { Hutan Lancar }} \times 100 \%
$$

2) Rasio Solvabilitas merupakan rasio yang menunjukan bagaimana perusahaan mampu untuk mengelola hutangnya dalam rangka memperoleh keuntungan dan juga mampu untuk melunasi kembali hutangnya. Adapun rasio yang diukur dalam Sovabilitas ini adalah total hutang dibagi dengan total modal dari tahun 2009 2014 di Perusahan Mira Mar Block Dili Timor leste.

$$
\text { Rasio Hutang atas modal }=\frac{\text { Total Hutang }}{\text { Modal (equity) }} \times 100 \%
$$

3) Rasio Aktivitas merupakan rasio yang menggambarkan sejauh mana suatu perusahaan mempergunakan sumber daya yang dimilikinya guna menunjang aktivitas perusahaan, dimana penggunaan aktivitas ini dilakukan secara sangat maksimal dengan maksud memperoleh hasil yang maksimal pula. Adapun rasio yang diukur dalam Aktivitas ini adalah total penjualan dibagi dengan total aktiva dari tahun 2009 -2014 di Perusahan Mira Mar Block Dili Timor leste. 
Alexandre de Jesus Lay, I.G.B. Wiksuana., Pengaruh Likuiditas, Solvabilitas, dan Aktivitas..

Fixed Asset Turnover $=\frac{\text { penjualan }}{\text { aktiva tetap }} \times 100 \%$

4) Profitabilitas (Y)

Profitabilitas menunjukkan kemampuan perusahan Mira Mar Block memperoleh laba dari modal yang digunakan tahun 2009 sampai dengan 2014 diukur dengan ROA (Return on Asset) merupakan rasio untuk mengukur keemampuan manajemen perusahaan dalam mengelola moda yang ada untuk mendapatkan net income (Kasmir, 2011). Adapun rasio yang diukur dalam Profitabilitas ini adalah total laba bersih di bagi dengan total aktiva dari tahun 2009 -2014 di Perusahan Mira Mar Block Dili Timor leste.

$$
R O A=\frac{\text { Laba Bersih }}{\text { Total Aktiva }} \times 100 \%
$$

\section{Pengumpulan Data}

1. Data kuantitatif yaitu jenis data atau informasi yang dapat dinyatakan dengan angka yang dapat dihitung. Data dalam penelitian ini merupakan data sekunder. Data yang pengumpulan dan pengelolahannya dilakukan oleh pihak lain yang didapat dari manager perusahaan berupa laporang keuangan, neraca dan laporan rugi laba perusahaan periode 2009 -2014.

2. Data kualitatif yaitu data yang tidak berupa angka atau tidak dinyatakan dalam suatu terrtentu, namun berupa keterangan atau uraian mengenai perusahaan periode $2009-2014$. 


\section{Teknik Analisa Data}

Untuk memecahkan permasalahan dalam penelitian sesuai dengan tujuan yang ingin dicapai maka digunakan analisis regresi liner bergada.

\section{Analisis Regresi Liner Berganda}

Dalam penelitian ini digunakan pendekatan SPSS untuk mencari pengaruh antara variabel tersebut dengan model regresi berganda yaitu:

$$
\mathrm{Y}=\mathrm{bo}+\mathrm{b} 1 \mathrm{x} 1+\mathrm{b} 2 \mathrm{x} 2+\mathrm{b} 3 \times 3+\mathrm{e}
$$

Keterangan:
a. Y
: Profitabilitas
b. $\mathrm{X}_{1}$
: Likuiditas
c. $\mathrm{X}_{2}$
: Solvabilitas
d. $\mathrm{X}_{3}$
: Aktivitas
e. Bo
: Costanta
f. b1,b2, b3 : Koefisien
g. g.e : Standar Eror

\section{Pengujian Asumsi Klasik}

Menurut Suyana Utama (2007:89) sebelum model regresi digunakan untuk memprediksi beberapa peneliti mengangap perlu mengguji kelayakan model yang dibuat. Untuk itu dilakukan pengujian asumsi klasik yang meliputi Uji Normalitas, Uji Autokorelasi, Uji Multikolineritas, dan Uji Heteroskedastisitas.

\section{Uji Normalitas}


Alexandre de Jesus Lay, I.G.B. Wiksuana., Pengaruh Likuiditas, Solvabilitas, dan Aktivitas..

Uji normalitas bertujuan untuk menguji apakah dalam residul dari model regresi yang dibuat berdistribusi normal atau tidak. Model regresi yang baik adalah memiliki distribusi residul yang normal atau mendekati normal. Umumnya regresi dengan residul yang berdistribusi normal diperoleh dari variabel terkait dan variabel bebas keduanya mempunyai distribusi normal ataukah tidak.

Dalam penelitian ini, untuk menguji apakah disttribusi data normal, pertama dapat dilakukan dengan melihat normal probability plot yang membandingkan distribusi kumulatiff dari data sesungguhnya dengan distribusi kumulatif dari dristribusi normal. Jika titik-titik menyebar mendekati garis diagonal maka data tersebut dianggap berdistribusi normal.

Kriteria pengujiannya:

Ho diterima bila $t_{\text {hitung }} \geq t_{\text {tabel }}$

Ho ditolak bila $t_{\text {hitung }}>t_{\text {tabel }}$

\section{Uji Autokorelasi}

Untuk melacak danya korelasi auto atau pengaruh data dari uji pengamatan sebelumnya dalam model regresi diatas dilakukan uji autokorelasi. Jika suatu model regresi mengandung geijala autokorelasi, maka prediksi yang dilakukan dengan model tersebut aakan tidak baik, atau dapat memberikan hasil prediksi yang menyimpang. Uji autokorelasi dapat dilakukan dengan Uji Durbin -Watson (DW-test) atau data statistik terhadap variabel prengganggu (disturbance errror trem).

Dalam uji DW ini, kriteria yang harus dipenuhi adalah sebagai berikut. 


\begin{tabular}{lcc}
\multicolumn{2}{c}{ Tabel 1 } \\
Peneriman dan Penolakan Ho Durbbin-Watson \\
\multicolumn{1}{c}{ Ho } & \multicolumn{1}{c}{ Jika } & Keputussan \\
\hline Tidak ada autokorelasi positif & $0<\mathrm{d}<\mathrm{dl}$ & Tolak \\
Tidak ada autokorelasi positif & $\mathrm{d} \mathrm{l} \leq \mathrm{d} \leq \mathrm{du}$ & No decision \\
Tidak ada autokorelasi negative & $4-\mathrm{d} \mathrm{l}<\mathrm{d}<4$ & Tolak \\
Tidak ada korelasi negative & $4-\mathrm{du} \leq \mathrm{d} \leq 4-\mathrm{dl}$ & No deecision \\
Tidak ada autokorelasi positif atau negative & $\mathrm{Du}<\mathrm{d}<(4-\mathrm{du})$ & Tidak tolak
\end{tabular}

Sumber: Imam Ghozali (2006:100)

\section{Uji Multi kolinearitas}

Uji multikolinearitas berrttujuan untuk menguji apakah pada model regresi ditemukan adanya korelasi antar variabel bebas. Model regresi yang baik seharusnya tidak terjadi korelasi diantara variabel bebas. Model regresi yang baik adalah bebas dari gejala multikolinearitas. Jika suatu model regresi yang mengandung gejala multikolinearitas dipaksakan untuk digunakan, maka akan memberikan hasil prediksi yang menyimpang. Untuk mendeteksi ada atau tidaknya korelasi antar sesama variabel bebas dapat dilihat dari nilai tolerance dan nilai variance inflation factor (VIF). Jika nilai tolerance lebih dari 10 persen atau VIF kurang dari 10, maka dikatakan tidak ada multikolinearitas. Adanya gejala multikuliner sering diindikasikan oleh $\mathrm{R}^{2}$ yang sangat besaratau uji $\mathrm{F}$ yang signifikan, tetapi variabel bebas yang signifikan melalui uji parsial (t) sedikit atau mungkin tidak ada. 
Alexandre de Jesus Lay, I.G.B. Wiksuana., Pengaruh Likuiditas, Solvabilitas, dan Aktivitas..

\section{Uji Heteroskedastisitas}

Uji heteroskedastisitas bertujuan menguji apakah dalam model regresi terjadi ketidasamaan varians dari residul satu pengamatan ke pengamatan yang lain. Model regresi yang baik adalah yang tidak mengandung gejala heteroskedastisitas atau mempunyai varians homogen. Jika suatu model regresi yang mengandung gejala heteroskedastisitas akan memberikan hasil prediksi yang menyimpang.

Tabel 2

Statistic Deskriptif variabel Likuiditas, Solvabilitas, Aktivitas dan Profitabilitas Descriptive Statistisk

\begin{tabular}{|c|c|c|c|c|c|}
\hline & $\mathrm{N}$ & Minimum & Maximum & Mean & Std.Deviation \\
\hline Likuiditas (x1) & 6 & 15.06 & 48.20 & 29.0067 & 12.39599 \\
\hline Solvabilitas (x2) & 6 & 1.00 & 1.51 & 1.3017 & 0.21170 \\
\hline Aktivitas (x3) & 6 & 1.39 & 259.00 & 98.1383 & 111.171 \\
\hline & 6 & 54.07 & 76.87 & 63.6600 & 8.39355 \\
\hline
\end{tabular}

Sumber: nomor lampiran

Berdasarkan Tabel 2 dapat dirumuskan bahwa variabel profitabilitas (y) yang memiliki rata-rata hitung mean sebesar 29.0067 artinya rata-rata tingkat keuntungan (pengembalian) dari modal sendiri yang diinvestasikan perusahaan selama periode 2009-2014 adalah sebesar 63.6600 perbulan. Standar deviasi (simpangan baku) variabel profitabilitas adalah 8.39355 selama perbulan pengamatan, variasi profitabilitas pada perusahaan menyimpang dari rata-ratanya sebesar 8.39355 .

Profitabilitas terendah (minimum) selama periode pengamatan yaitu pada perusahaan Mira Marak block yaitu 54.07. Profitabilitas tertinggi (maksimum) selama periode pengamatan yaitu pada perusahaan Mira Marak Block 76.87. 
Variabel Likuiditas $\left(\mathrm{X}_{1}\right)$ yang memiliki rata-rata hitung mean sebesar 15.06 artinya rata-rata semakin cepat periode berputarnya maka menunjukkan semakin cepat penjualan kredit dapat kembali menjadi kas perusahaan selama periode 2011-2013 adalah sebesar 29.0067 perbulan. Standar deviasi (simpangan baku) variabel Likuiditas adalah 12.39566 selama perbulan pengamatan,variasi Likuiditas. Sedangkan perputan kas terendah (minimum) selama periode pengamatan yaitu pada mira marak blok yaitu 15.06. Likuiditas tertinggi (maksimum) selama perode pengamatan yaitu pada perusahaan Mira Marak Blok sebesar 48.20

Variabel Solvabilitas (x2) yang memiliki rata-rata hitung sebesar 1.3017 artinya semakin tinggi Solvabilitas akan semakin baik, karena ini berarti semakin tinggi efisiensi penggunaan piutangnya dan keuntungan yang diperoleh akan semakin besar. Perusahaan selama periode 2009 -2014 adalah 1.3017 perbulan. Standar deviasi (simpangan baku) variabel Solvabilitas adalah 0.21170 selama perbulan pengamatan, variasi Solvabilitas. Sedangkan Solvabilitas terendah (minimum) selama periode pengamatan yaitu pada perusahaan Mira Mar Block yaitu 1.00. Solvabilitas tertinggi (maksimum) selama perode pengamatan yaitu pada perusahaan Mira Marak Block sebesar 1.51.

Variabel Aktivitas (x3) yang memiliki rata-rata hitung mean sebesar 98.1383 artinya semakin tinggi tingkat Aktivitas akan memperkecil resiko terhadap kerugian yang disebabkan karena penurunan harga atau karena perubahan selera konsumen, disamping itu akan menghemat ongkos penyimpanan dan pemeliharaan terhadap persediaan tersebut. Perusahaan selama periode 2009- 
Alexandre de Jesus Lay, I.G.B. Wiksuana., Pengaruh Likuiditas, Solvabilitas, dan Aktivitas..

2014 adalah 98.1383 perbulan. Standar deviasi (simpangan baku) variabel Aktivitas adalah 111.17193 selama perbulan pengamatan, variasi Aktivitas. Sedangkan Aktivitas terendah (minimum) selama periode pengamatan yaitu pada perusahaan Mira Marak Block yaitu 1.39. Aktivitas tertinggi (maksimum) selama perode pengamatan yaitu pada perusahaan Mira Marak Block sebesar 259.00.

\section{Pengujian Asumsi Klasik}

Dalam pengujian dengan analisis Regresi diperlukan adanya pengujian dengan mempertimbangkan kemungkinan adanya penyimpangan terhadap asumsi klasik. Jika masih terdapat penyimpangan asumsi klasik selanjutnya akan dilakukan revisi terhadap data penelitian maupun model Regresi. Pengujian penyimpangan asumsi klasik yang terdiri atas gejala normalitas, autokorelasi, multikolinearitas, dan heterokedastisitas. Pengujian-pengujian tersebut dapat diuraikan sebagai berikut:

\section{Hasil Uji Normalitas}

Hasil uji normalitas disajikan pada Tabel 3

Tabel 3

Hasil Tests of Normality

One-Sample Kolmogorov-Smirnov Test

\begin{tabular}{|ll|r|}
\hline & & \multicolumn{1}{c|}{$\begin{array}{c}\text { Unst. } \\
\text { Residual }\end{array}$} \\
\hline N & & 6 \\
Normal Parameters ${ }^{\mathrm{a}, \mathrm{b}}$ & Mean & .0000000 \\
& Std. Dev iation & .05793627 \\
Most Extreme & Absolute & .307 \\
Diff erences & Positive & .285 \\
& Negative &. .307 \\
Kolmogorov-Smirnov Z & & .751 \\
Asy mp. Sig. (2-tailed) & & .625 \\
\hline
\end{tabular}

a. Test distribution is Normal.

b. Calculated from data. 
Sumber: Lampiran 1

Berdasarkan hasil analisis dengan menggunakan SPSS didapat nilai signifikansi uji Kolmogorom-Smirnov 0,625 yang jauh di atas 0,05 sehingga dapat dikatakan bahwa data berdistribusi normal.

\section{b). Hasil Uji Autokorelasi}

Uji autokorelasi bertujuan untuk menguji apakah model regresi linear ada korelasi antara kesalahan penggangu pada periode t-1 (sebelumnya), menurut Ghozali, (2006) model regresi yang baik adalah regresi yang bebas dari autikorelasi.

Berdasarkan hasil analisis dengan mengunakan SPSS pada Lampiran 1, didapat nilai Durbin-Watson sebesar 2,564. Nilai table DW (Lampiran 2) dengan signifikan 0,05 dengan jumlah data $(n)=6$ dan jumlah variabel independent $(k)$ $=3$, menghasilkan nilai DL sebesar 0,610, dan DU sebesar 1,400 sehingga nilai 4DU menjadi 2,6. Nilai DW sebesar 2,56 terletak antara nilai DU dan 4-DU, maka dapat disimpulkan bahwa model persamaan regresi tersebut ada mengadung masalah otokorelasi.

\section{c). Uji Multikolinearitas}

Uji multikolinearitas digunakan untuk mengetahui ada atau tidaknya penyimpangan asumsi klasik multikonearitas, yaitu adanya hubungan linear antar model regresi adalah tidak adanya multikolinearitas (Wiyono,211).Menurut Suliyanto (2011), pada umumnya jika VIF tidak lebih dari 10 maka model dinyatakan tidak terdapat gejala multikolinier. Untuk mengetahui terjadi 
Alexandre de Jesus Lay, I.G.B. Wiksuana., Pengaruh Likuiditas, Solvabilitas, dan Aktivitas..

multikolinearitas dapat dilihat dari nilai VIF yang terdapat pada masing-masing variabel berikut

\section{Tabel 4}

Hasil Uji Multikolinearitas

Variabel Likuiditas, Solvabilitas, Aktivitas, dan Profitabilitas

\begin{tabular}{lcc}
\hline \multicolumn{1}{c}{ Variabel } & Tolerance & VIF \\
\hline Likuiditas & 0,137 & 7,925 \\
Solvabilitas & 0,252 & 3,974 \\
Aktivitas & 0,342 & 2,923 \\
\hline
\end{tabular}

Berdasarkan Tabel 4 diperoleh bahwa semua variabel bebas memiliki nilai Tolerance di bawah 1 dan nilai VIF di bawah angka 10. Dengan demikian dalam model ini tidak ada masalah multikolinieritas.

\section{Uji Ketepatan Model Regresi}

Untuk mengetahui ketepatan model regresi dalam penelitian ini, digunakan uji F. Berdasarkan analisis pada Lampiran 1, di dapat nilai F hitung sebesar 1189,712 dengan nilai signifikansi sebesar 0,001. Karena nilai signifikansi uji $\mathrm{F}$ lebih kecil dari 0,05 maka dapat disimpulkan bahwa model regresi ini sudah tepat. Hasil ini menunjukkan bahwa semua variabel bebas (secara simultan) tepat digunakan sebagai variabel prediktor yang mempengaruhi variabel terikat. Besarnya pengaruh variabel bebas terhadap variabel terikat adalah sebesasr nilai R square, yaitu 0,999. Angka ini menunjukkan bahwa 99,9\% perubahan nilai profitabilitas ditentukan oleh Likuiditas, Solvabilitas dan Aktivitas, sedangkan sisanya $1 \%$ ditentukan oleh variabel di luar model.

\section{Hasil Pengujian Hipotesis}


Pengujian hipotesis untuk mengetahui pengaruh langsung variabel likuiditas, solvabilitas dan aktivitas terhadap profitabilitas dapat dilihat pada Tabel 5

Tabel 5

Hasil Regresi Pengaruh Langsun Variabel Likuiditas, Solvabilitas Dan Aktivitas Terhadap Profitabilitas

Coefficients ${ }^{\mathrm{a}}$

\begin{tabular}{|c|c|c|c|c|c|c|}
\hline \multirow{2}{*}{\multicolumn{2}{|c|}{ Model }} & \multicolumn{2}{|c|}{$\begin{array}{l}\text { Unstandardized } \\
\text { Coeff icients }\end{array}$} & \multirow{2}{*}{$\begin{array}{c}\text { Standardized } \\
\text { Coeff icients } \\
\text { Beta }\end{array}$} & \multirow[b]{2}{*}{$\mathrm{t}$} & \multirow[b]{2}{*}{ Sig. } \\
\hline & & $\mathrm{B}$ & Std. Error & & & \\
\hline \multirow[t]{4}{*}{1} & (Constant) & 17.859 & 2.383 & & 7.495 & .017 \\
\hline & Likwinditas & .005 & .000 & 1.065 & 23.566 & .002 \\
\hline & Solvabilitas & -1.026 & .100 & -.341 & -10.220 & .009 \\
\hline & Aktiv itas & .135 & .006 & .659 & 23.025 & .002 \\
\hline
\end{tabular}

a. Dependent Variable: ROA

Sumber : Lampiran 1

\section{Pembahasan}

a. Pengaruh Likuiditas terhadap Profitabilitas

Hasil analisis seperti yang ditunjukkan pada Tabel 5 terlihat bahwa variabel Likuiditas memiliki koefisien regresi sebesar 0,005 dengan nilai signifikansi uji t sebesar 0,002. Nilai signifikansi uji t yang lebih kecil dari 0,05 menunjukkan bahwa ada pengaruh positif yang signifikan variabel Likuiditas terhadap Profitabilitas. Makin tinggi nilai Likuiditas maka nilai Profitabilitas juga akan meningkat. Hal ini menujukan bahwa likuiditas mampu meningkatkan profitabilitas ( ROA) pda perusahan Mira Mar Block Building Industry

b. Pengaruh Solvabiltas terhadap Profitabilitas

Hasil analisis seperti yang ditunjukkan pada Tabel 5 terlihat bahwa variabel Solvabilitas memiliki koefisien regresi sebesar -1,026 dengan nilai signifikansi uji t sebesar 0,009. Nilai signifikansi uji t yang lebih kecil dari 0,05 menunjukkan 
Alexandre de Jesus Lay, I.G.B. Wiksuana., Pengaruh Likuiditas, Solvabilitas, dan Aktivitas..

bahwa ada pengeruh negatif yang signifikan variabel Solvabiltas terhadap Profitabilitas Pada Perusahan Mira Mar Block Building Industry. Makin tinggi nilai Solvabilitas maka nilai Profitabilitas juga akan menurun.

c. Pengaruh Aktivitas terhadap Profitabilitas

Hasil analisis seperti yang ditunjukkan pada Tabel 39 terlihat bahwa variabel Aktivitas memiliki koefisien regresi sebesar 0,135 dengan nilai signifikansi uji t sebesar 0,002. Nilai signifikansi uji t yang lebih kecil dari 0,05 menunjukkan bahwa ada pengeruh positif yang signifikan variabel Aktivitas terhadap Profitabilitas. Makin tinggi nilai Aktivitas maka nilai Profitabilitas juga akan meningkat. Pada perusahan Mira Mar Block Building Industry. Keterbatasan

\section{Penelitian}

Penelitian ini terbatas menganalisis variabel Likuiditas, Solvabilitas dan Aktivitas mempengaruhi Profitabilitas serta data dengan periode 2009-2014 yang sama antara kinerja keuangan dengan nilai profitabilitas pada perusahaan.

\section{Simpulan dan Saran}

Berdasarkan hasil pembahasan sebelumya maka penulis menarik kesimpulan sebagai berikut: Variabel Likuiditas berpengaruh positif dan signifikan terhadap Profitabilitas, Variabel Solvabilitas berpengaruh negatif dan signifikan terhadap Profitabilitas, Variabel Aktivitas berpengaruh positif dan signifikan terhadap Profitabilitas. Secara simultan, variabel Likuiditas, Solvabilitas dan Aktivitas berengaruh signifikan terhadap profitabilitas.

Perusahaan harus meningkatkan rasio Likuiditasnya karena dapat meningkatkan Profitabiltas perusahaan. Perusahaan juga harus mengelola dengan 
baik rasio Solvabilitasnya karena dapat mempengaruhi Profitabilitas perusahaan. Rasio Aktivitas perusahaan juga harus ditingkatkan untuk meningkatkan nilai profitabilitas.

\section{REFERENSI}

Kasmir.210 pengantar Manajemen keuangan,Edisi pertama,kencana Jakarta Kasmir.2012 .Analisa laporan keuangan.cetakan keeanam.jakarta: PT raja grafindo.

Lazaridis, I \& Tryfonidis,D.2006 relationship between working capital management and

profitability of listend companies in the anthens stock. Exchange.journal of financial Manajemen and Analysis, Vol.19,No.1,January-june 2006.

Anthony, R. N., \& Govindarajan, V. (2007). Management Control Systems. New York: McGraw-Hill.

Bodie, Z. K., Kane, A., \& Marcus, A. J. (2008).Investment (7th edition). NewYork: McGraw-Hill.

Damodaran, Aswath. (2002). Investment Valuation. NewYork: McGraw-Hill.

Ehrbar, A., \& Stewart, S. (1998). EVA: The Real Key to Creating Wealth. Canada:

John Wiley \& Sons, Inc.

Knight, A James. (1997)Value Based Management, Developing A Systematic Approach to Creating Shareholder Value, NewYork: McGraw Hill

Libby, R., Libby, P. A., \& Short, D. G. (2004).Financial Accounting (4thEdition). New York: McGraw-Hill.

Palepu, Healy, Bernard (2004). Business Analyst and Valuation using Financial Statement. United State, Thomson.

Ross, S. A., Westerfield, R. W., Jaffe, J., \& Jordan, B. D. (2008).Modern Financial Management. New York: McGraw-Hill. 
Alexandre de Jesus Lay, I.G.B. Wiksuana., Pengaruh Likuiditas, Solvabilitas, dan Aktivitas..

Stern, J. M., \& Shiely, J. S. (2001).The EVA Challenge (Implementing Value Added Change In An Organization. Canada: John Wiley \& sons, Inc.

Stewart, G. B. (1991).The quest for value: a guide for senior managers.NewYork: Harpe Collins.

Wild, J. J., Subramanyam, K. R., \& Halsey, R. F. (2007). Financial Statement Analysis (Ninth Edition). NewYork: McGraw-Hill.

Young, S. D., \& O'Byrne, S. F. (2001).EVA and Value Based Management, Practical Guide to Implementation. NewYork: McGraw Hill.

http://pages.stern.nyu.edu/ adamodar/

http://www.yahoofinance.com

http://www.wikipedia.com

http://www.investopedia.com 